\title{
NOTE
}

\section{Encephalomyelitis among turbot associated with a picornavirus-like agent}

\author{
Buchardt Bloch $^{1}$, Kjersti Gravningen ${ }^{2}$, Jens Laurits Larsen ${ }^{1, *}$ \\ ${ }^{1}$ Department of Veterinary Microbiology, The Royal Veterinary and Agricultural University, Bülowsvej 13, DK-1870 Frederiksberg C, Denmark \\ ${ }^{2}$ Tinfos Aqua A/S, Øyestranda, Norway
}

ABSTRACT: An outbreak of encephalomyelitis among larval turbot Scophthalmus maximus caused very heavy mortalities. Bacteriological findings were very unspecific, and parasites were not observed. By electron microscopy large numbers of virus particles were found in the brain and medulla of the diseased fish. Based on the size of the particles and their position in the cytoplasm of the infected cells it is suggested that the particles belong to the picornaviridae. The neurotropic character of the disease further suggests that the virus might be an enterovirus.

Parallel with the development of hatching and larval rearing techniques of new species in aquaculture, new disease problems of parasitological, bacterial, and viral origin occur.

In turbot production, vibriosis appears to be a common problem, and we have hitherto isolated Vibrio anguillarum serogroups $01,02 \mathrm{a}$, and $02 \mathrm{~b}$ as well as members of the Vibrio splendidus/pelagius group. A more complex ulcerative disease has been described in Spain involving 3 facultative pathogens, Vibrio carchariae, Myxobacteria, and a protozoan resembling Cryptocaryon spp. (Devesa et al. 1989).

Viral agents demonstrated in turbot include 'Herpesvirus scophthalmi' (Buchanan \& Madeley 1978), infectious pancreatic necrosis virus (Castric et al. 1987) and a virus which was suggested to be a member of the Reovirus group (Lupiani et al. 1989).

This report deals with an investigation of a disease associated with heavy mortalities among young turbot Scophthalmus maximus in a Norwegian fish farm.

Materials and methods. The disease problem appeared in an extensive production unit near Bergen, Norway. Turbot larvae were reared in 18 floating bags $\left(50 \mathrm{~m}^{3}\right)$ in a marine lagoon $\left(140000 \mathrm{~m}^{3}\right)$. The bags were stocked with 80000 to 150000 eggs per batch at the

\footnotetext{
- Author for correspondence
}

beginning of June 1989. The temperature was 12 to $13^{\circ} \mathrm{C}$ at the time of stocking, but increased gradually to 17 or $18{ }^{\circ} \mathrm{C}$ over the next 2 to $3 \mathrm{wk}$, with surface water temperatures reaching $20^{\circ} \mathrm{C}$ around noon. In late June the weather changed, and heavy rainfall, accompanied by a drop in surface temperatures to between 14 and $15^{\circ} \mathrm{C}$, occurred. The larvae were fed zooplankton collected from the lagoon. They seemed to develop normally until the beginning of July, when heavy mortality occurred.

In the first batch of larvae, the mortality appeared during weaning to moist pellets (weight 50 to $100 \mathrm{mg}$ ). Later, the clinical signs associated with the mortality in the first batch were observed among other batches of larvae in the lagoon. The last batches, stocked in August 1989, died within 3 wk after hatching. Fish transferred to weaning tanks that exhibited mortalities were treated with antibiotics (Nifurazolidone). This did not reduce mortality.

The initial clinical signs were reduced feeding activity followed by a darkening in pigmentation. Diseased fish became lethargic, often lying abdomen-up on the bottom. Atypical swimming, such as rotating, spinning, and horizontal looping, was observed when the fish were disturbed. The clinical signs indicated disturbance of the central nervous system and were followed by $100 \%$ mortality.

Samples were taken from internal organs (pronephros, liver, spleen) and plated on tryptic soy agar containing $2 \% \mathrm{NaCl}$ or marine agar (Difco) with $5 \%$ citrated calf blood, and TCBS agar (Difco). Incubation was at $20^{\circ} \mathrm{C}$ for $48 \mathrm{~h}$. Resulting isolates were characterized according to West \& Colwell (1984) and Larsen (1985).

Gills, skin, and intestine were examined for the presence of parasites by light microscopy. 
The brain-containing part of the heads of 5 fish together with the internal organs from 2 fish, gills from 4 fish, and the medulla-containing part of 3 fish were fixed in $2.5 \%$ glutaraldehyde in a phosphate buffer $(0.13 \mathrm{M})$ and post-fixed in $1 \%$ osmium tetroxide. After dehydration in acetone, the samples were embedded with Vestopal-W (Serva). Survey sections (1 to $3 \mu \mathrm{m}$ ) were stained with toluidine blue and examined in the light microscope in order to locate affected tissues. Ultrathin sections of such areas were stained in uranyl acetate and lead citrate and examined in a JEM 100B transmission electron microscope. A diffraction grating was used for calibration.

Results. Bacteriological examination of the fish showed that several plates were sterile, while others showed sparse growth of a mixed culture in which the following Vibrio species were isolated:

$V$. splendidus biovar I; $V$. splendidus, biovar II; $V$. alginolyticus; $V$. pelagius; $V$. fisheri; $V$. anguillarum'like'.
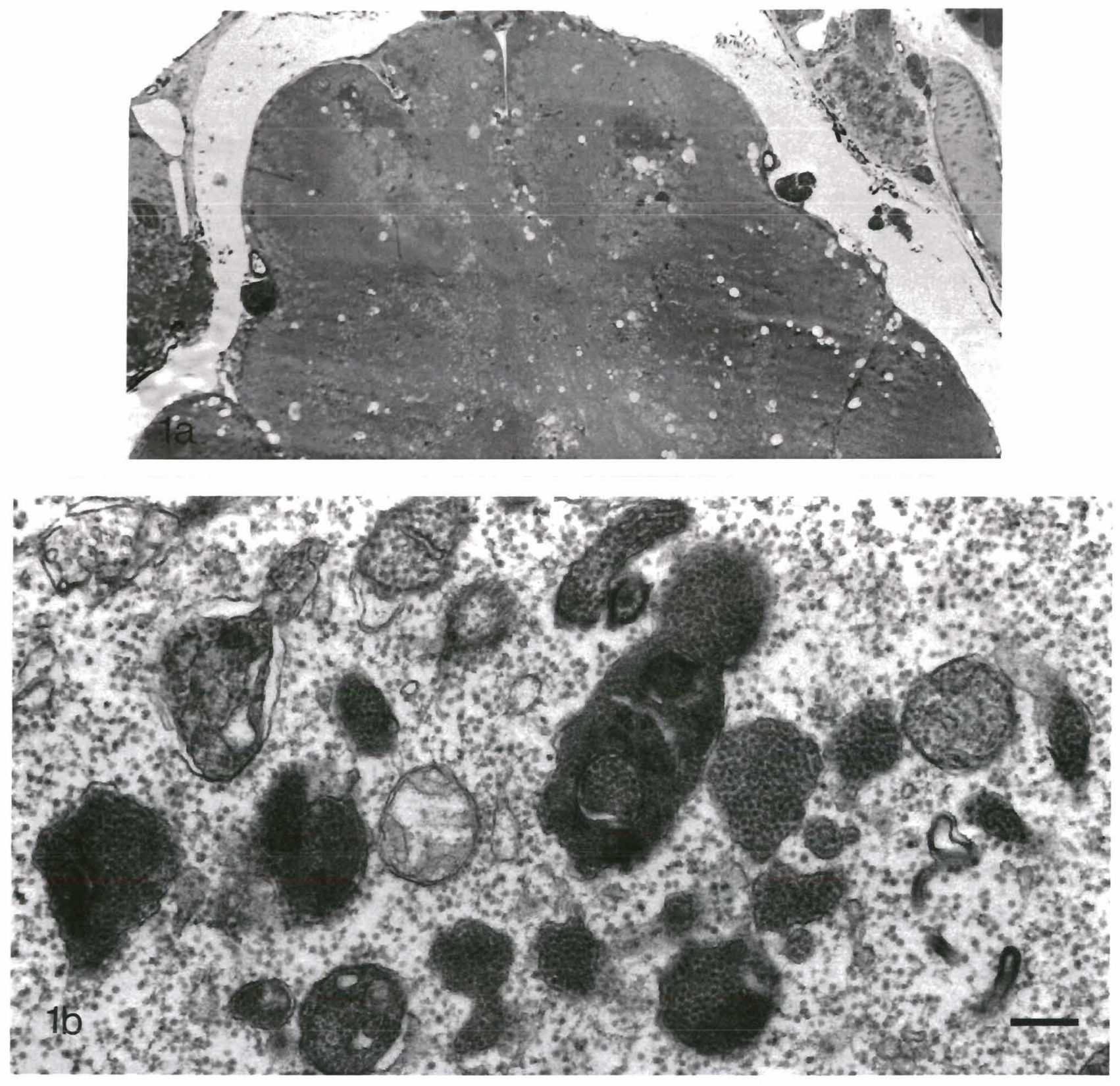

Fig. 1. Scophthalmus maximus. (a) Light micrograph of a horizontal section of the brain of a turbot larva of total length $17 \mathrm{~mm}$ showing vacuolation in the granular areas. Toluidine blue $(\times 100)$. (b) Part of a brain cell containing pleomorphic bodies filled with virus-like particles. Some of the particle-containing bodies seem to be formed by fusion of smaller bodies. Large numbers of virus-like particles are scattered freely in the cytoplasm. Bar $=250 \mathrm{~nm}$ 
Because of the high diversity of bacteria present we suspected bacterial infection not to be the primary cause of the mortalities.

The parasitological examinations were all negative.

Histological examinations of the survey sections revealed conspicuous brain lesions in all fish examined. Many of the pericarya of the neurons contained several large vacuoles in the cytoplasm. Vacuolated cells were present in all parts of the brain, but most frequently in the parts containing many cell bodies (Fig. 1a). Similar vacuolated cells were observed in the medulla, but in smaller numbers.

Transmission electron microscopy of brain tissue containing vacuolated cells revealed cells containing dense pleomorphic bodies filled with virus-like particles (Fig. 1b). In the dense bodies the virus-like particles were often arranged in crystalline or para-crystalline arrays. In some bodies amorphous material, probably viroplasm, was observed together with the viruslike particles. The bodies resembled secondary lysosomes because a surplus of multilaminated membrane material was often present in or around them (Fig. 2). Less dense bodies surrounded only by a unit membrane were also observed. These bodies were slightly dilated and usually rounded. They contained virus-like particles that were randomly distributed. The size of the bodies varied as some could contain only few particles, while others were larger than a nucleus and contained many particles (Fig. 3). Occasionally the unit membrane surrounding the larger granules had ruptured, allowing the virus-like particles to escape into the cytoplasm. In the vacuolated cells, the virus-like particles occurred in the vacuoles which thus appeared to be very dilated particle-containing bodies (Fig. 4). Although vacuolated cells were usually found in large numbers, they were not always present in an infected tissue. In such cases the particle-containing bodies were not sufficiently dilated to be observed by light microscopy.

The diameter of the virus-like particles averaged ca $29 \mathrm{~nm}$, while particles of the shape of regular hexagons measured ca $27 \mathrm{~nm}$ from side to side and $30 \mathrm{~nm}$ from corner to opposite corner. The particles had a dense nucloid measuring about $21 \mathrm{~nm}$ in diameter, surrounded by a double layer, ca $4.5 \mathrm{~nm}$ wide, the inner half of which was unstained. The particles usually appeared to be almost round (Fig. 5).

Some of the infected cells were very dilated and contained swollen mitochondria and dilated perinuclear cisternae. Such cells usually contained only few or

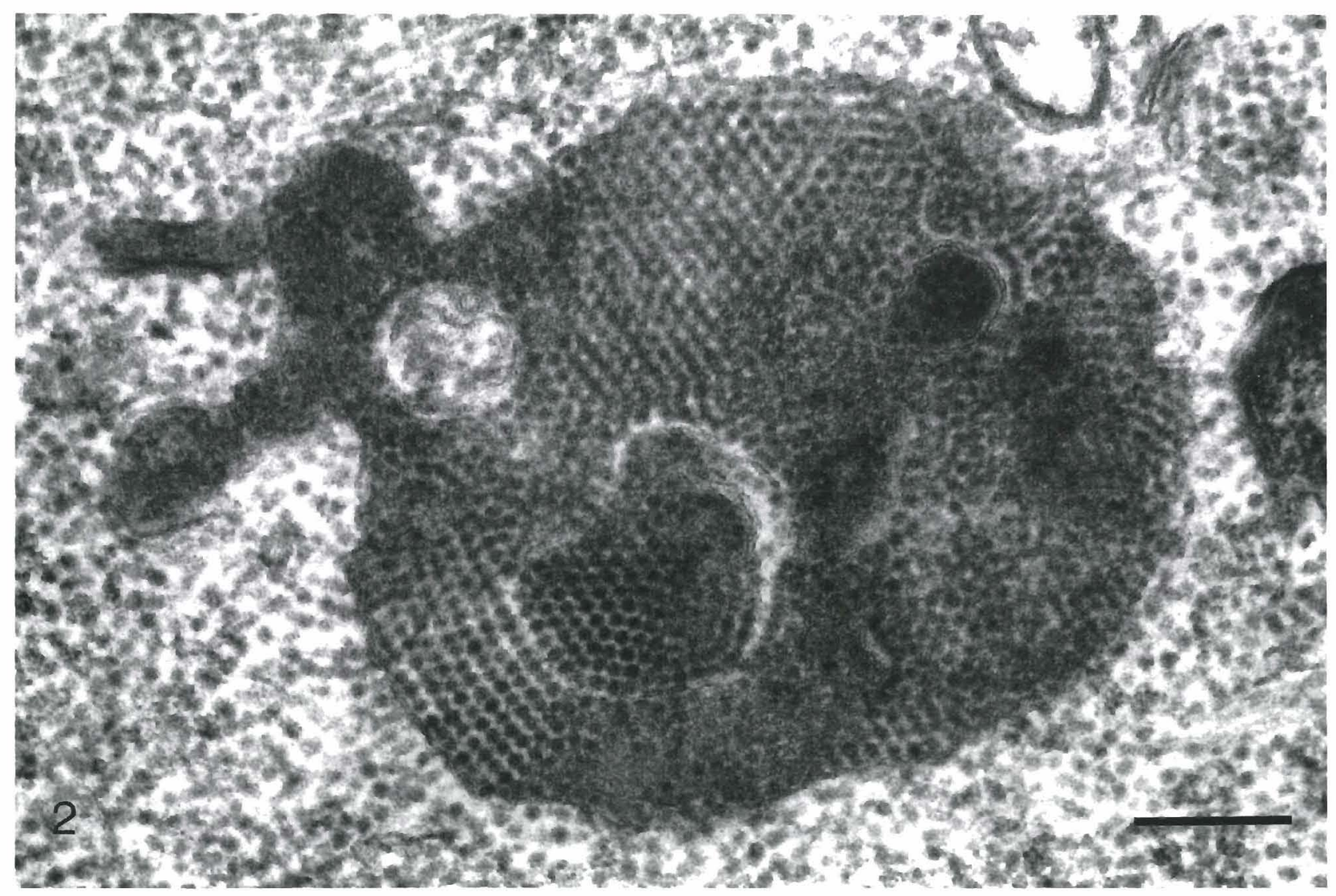

Fig. 2. Scophthalmus maximus. Part of a neuron from a turbot brain with a lysosome-like body filled with virus-like particles in a crystalline array. Note the areas of fine granular material assumed to be remaining viroplasm. Bar $=250 \mathrm{~nm}$ 


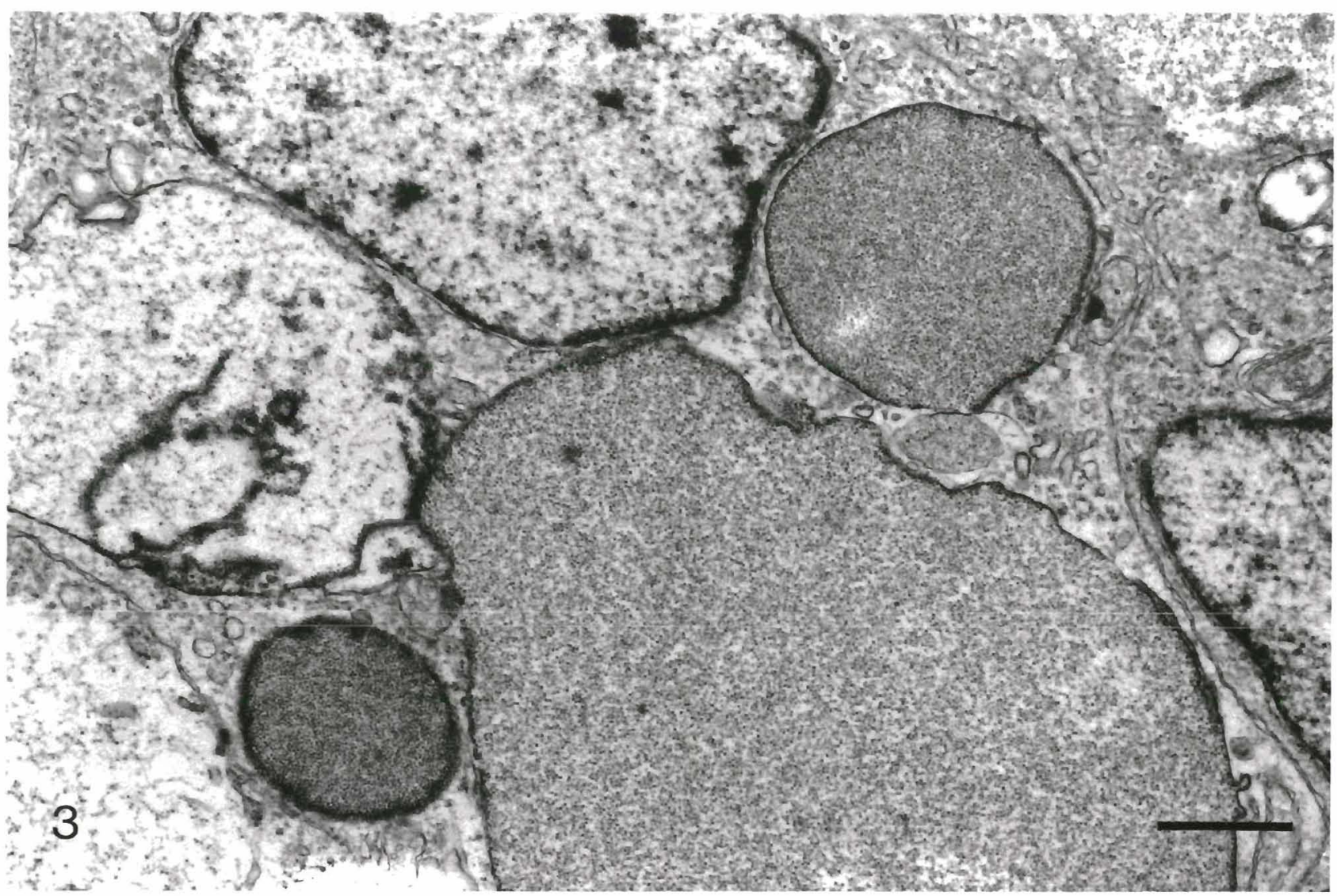

Fig. 3. Scophthalmus maximus. Unidentified brain cells containing rounded bodies filled with virus-like particles. One of these bodies (bottom left) as well as part of a neighbouring cell is verv dilated. Bar $=1 \mu \mathrm{m}$

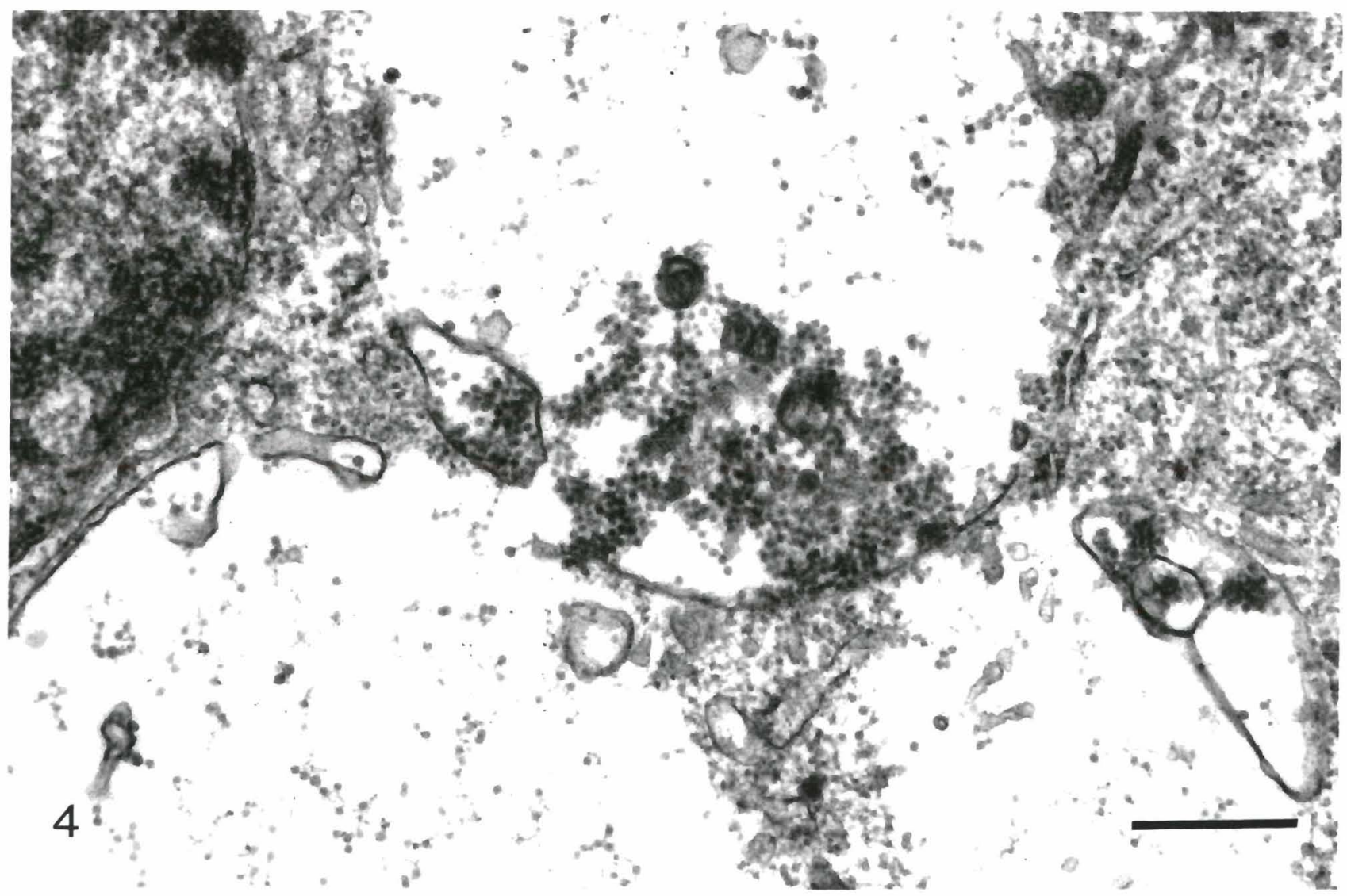

Fig. 4. Scophthalmus maximus. Part of a vacuolated brain cell. Vacuoles contain relatively few virus-like particles. Bar $=500 \mathrm{~nm}$ 


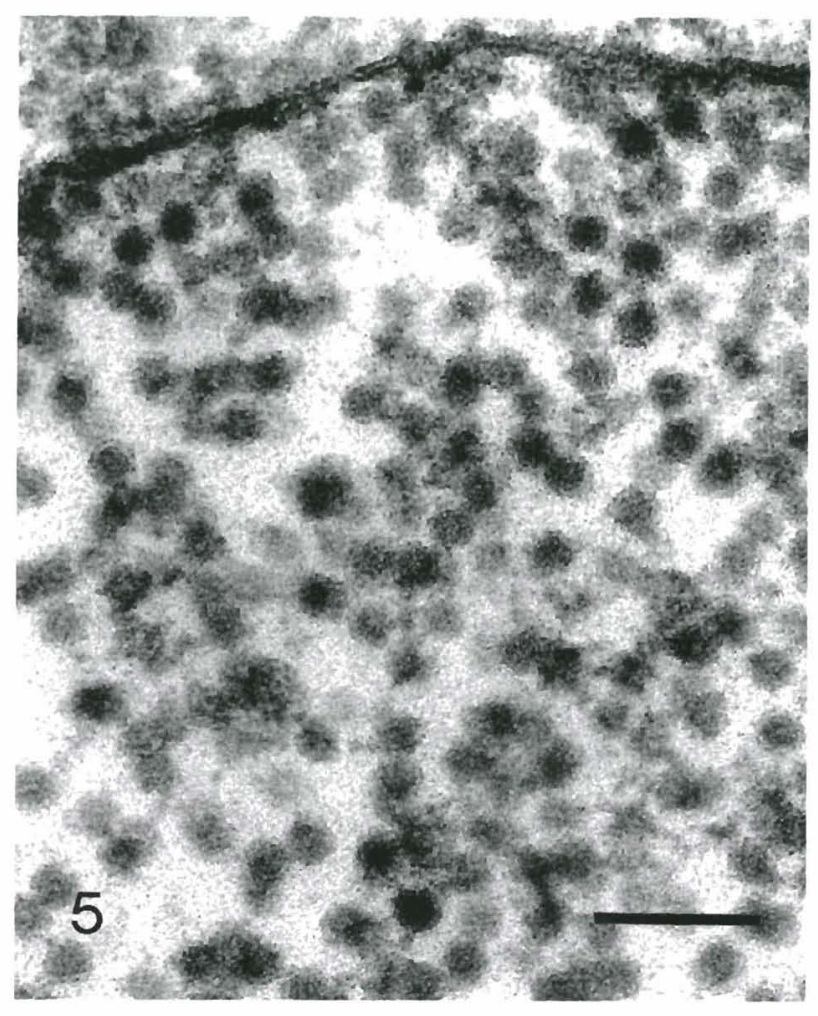

Fig. 5. Scophthalmus maximus. Part of a large particle-containing body filled with enterovirus-like particles. The limiting unit membrane of the body can be seen at top. Bar $=100 \mathrm{~nm}$

no particle-containing bodies. Acellular foci of the size of a few cells were also observed and may have represented the result of focal cytolysis.

The findings in the medulla were similar to those in the brain, although not necessarily identical to or in synchrony with those seen in the corresponding brain. In one case the particle-containing bodies in the medulla were generally much larger than the particlecontaining bodies in the brain. In another medulla no vacuolated cells were observed, but large numbers of dilated cells containing many virus-like particles both in and outside particle-containing bodies were present. A medulla without virus-like particles was also seen, although they were present in the brain of the same fish.

In one of the 5 brains examined, the meninges were also affected. Some of the meningeal cells contained virus-like particles in bodies or vacuoles similar to those in the brain and medulla. This means that cells other than neurons and glial cells were infected; however, due to the cytopathic effect, the infected cells generally could not be identified with certainty. Usually the brains did not show any signs of inflammation. In one brain, lymphocytes were observed in the affected parts of the meninges, and also a few cells, assumed to be lymphocytes, were seen in the part of the brain closest to the dilated meninges. The astrocytic processes below the meningeal basement membrane were sometimes dilated or ruptured in such areas.

No sign of viruses was observed in gills, intestines, liver, pancreas, or muscles.

Discussion. All the circumstances described above the size, the morphology, and the cytoplasmic replication - strongly indicate that the virus-like particle found is a virus belonging to the picorna family, among which the enteroviruses are notable for their neurotropic behaviour. While the enteroviruses of mammals, e.g. polio virus and Teschen virus, occur in the cytoplasm of the infected cells in cytoplasmic inclusions lacking limiting membranes, cells infected with an avian intestinal virus, described by McNulty et al. (1984), as well as the duck viral hepatitis virus, observed by Richter et al. (1964), show more or less crystalline virus inclusions limited by a membrane. Both of these viruses are considered to be enteroviruses. An agent believed to cause avian encephalomyelitis was also observed in membrane-bound lysosome-like structures (Asdrubali et al. 1972). These structures contained small groups of crystallically arranged, uniformly dense particles embedded in an amorphic substance. These particles measured only 18 $\mathrm{nm}$ in diameter. As avian encephalomyelitis virus measured from 24 to $32 \mathrm{~nm}$, depending on the preparation technique (Gosting et al. 1980), the particles described by Asdrubali et al. (1972) may have represented incomplete virions. It should be noted that the avian encephalomyelitis virus is classified as an enterovirus.

Based on the similarity to the avian enteroviruses mentioned above, it is suggested that the present viruslike particles could be considered an enterovirus.

The presence of a picornavirus or a picorna-like virus in fish has been documented in only a few papers. The first of these reports (Yong-Sin Lu 1983) linked an avian picornavirus to fish as it described the infection of carp with duck hepatitis virus. After the present paper was submitted for evaluation, 2 papers describing small viruses associated with lesions in the central nervous system of hatchery-reared fish larvae were published. In both papers the histopathological findings and the clinical signs were very similar to those of the encephalomyelitis noted in the turbot larvae, with vacuolation of the central nervous system as the most conspicuous finding. The report by Yoshikoshi \& Inoue (1990) deals with a disease with almost $100 \%$ mortality among larvae of Japanese parrotfish. A lower mortality was found among juvenile parrotfish which correlated with the fact that the lesions in juveniles were less extensive than those in larvae. By negative staining, the virus associated with the disease measured $34 \mathrm{~nm}$ in diameter, possibly indicating that it may not be a picornavirus. Probably for this reason the authors have 
not attempted to classify the virus. The other paper reports the finding of a picorna-like virus associated with mass mortalities among larval barramundi (Glazebrook et al. 1990). In addition to vacuolation of the brain, the authors also observed vacuolation in the retina and the intestinal mucosa of the hindgut. They also reported severe hypertrophy of the respiratory epithelium. The picorna-like virus of the larval barramundi measured 25 to $30 \mathrm{~nm}$ in diameter, which equals the size of the picorna-like virus of the turbot in our study. In barramundi larvae, the virus particles were observed only in the brain and retina. However, the authors intend to determine whether the vacuolation of the hindgut was also due to the picorna-like virus.

For comparative purposes it would be of great interest to determine whether the turbot virus in some larvae is replicated in the intestines and transmitted with the faeces. Also it would be of interest to invegestigate the prevalence of antibodies against the virus in both farmed and free-living turbots and the serological relationship between the present turbot virus and the corresponding viruses found in the Japanese parrotfish and in barramundi. However, before such projects can be carried out, a satisfactory system for culturing the viruses must be found. Culture of the turbot virus will be attempted in the near future.

Acknowledgements. We thank Joachim Stoss and Tor Solberg for valuable comments and suggestions and Helle Kürstein for typing the manuscript.

\section{LITERATURE CITED}

Asdrubali, G., Gialetti, L., Mughetti, L., Fioroni, A. (1972). Contributo allo studio della encefalomielite aviare:

Responsible Subject Editor: T. Evelyn, Nanaimo, B. C., Canada immunofluorescenza, istopatologia, microscopia elettronica. La Nuova Veterinaria 48: 360-374

Buchanan, J. S., Madeley, C. R. (1978). Studies on Herpesvirus scophthalmi infection of turbot Scophthalmus maximus (L.). Ultrastructural observations. J. Fish Dis. 1: 283-295

Castric, J., Baudin-Laurencin, F., Coustans, M. F., Auffret, M. (1987). Isolation of Infectious Pancreatic Necrosis virus AB serotype, from an epizootic in farmed turbot, Scophthalmus maximus. Aquaculture 67: 117-126

Devesa, S., Barja, J. L., Toranzo, A. E. (1989). Ulcerative skin and fin lesions in reared turbot (Scophthalmus maximus L.). J. Fish Dis. 12: 323-333

Glazebrook, J. S., Heasman, M. P., de Beer, S. W. (1990). Picorna-like viral particles associated with mass mortalities in larval barramundi, Lates calcarifer Bloch. J. Fish Dis. 13: 245-249

Gosting, L. H., Grinnell, B. W., Matsumoto, M. (1980). Physicochemical and morphological characteristics of avian encephalomyelitis virus. Vet. Microbiol. 5: 87-100

Larsen, J. L. (1985). Vibrio anguillarum: prevalence of typical and atypical strains in marine recipients with special reference to carbohydrate pollution. Acta vet. Scand. 26: $449-460$

Lupiani, B., Dopazo, C. P., Ledo, A., Fouz, B., Barja, J. L., Hetrick, F. M., Toranzo, A. E. (1989). New syndrome of mixed bacterial and viral ethiology in cultured turbot (Scophthalmus maximus L.). J. aquat. Anim. Health 1: 197-204

McNulty, M. S., Allan, G. M., Connor, T. J., McFerran, J. B., McCracken, R. M. (1984). An entero-like virus associated with the runting syndrome in broiler chickens. Avian Pathol. 13: 429-439

Richter, W. R., Rdzok, E. J., Moize, S. M. (1964). Electron microscopy of viruslike particles associated with duck viral hepatitis. Virol. 24: 114-116

West, P. A., Colwell, R. R. (1984). Identification and classification of Vibrionaceae - an overview. In: Colwell, R. R. (ed.) Vibrios in the environment, Chap. 20. John Wiley \& Sons, New York, p. 285-363

Yong-Sin Lu (1983). Epidemiological studies on duck viral hepatitis. J. Chinese Soc. Vet. Sci. 9: 11-18

Yoshikoshi, K., Inoue, K. (1990). Viral nervous necrosis in hatchery-reared larvae and juveniles of Japanese parrotfish, Oplegnathus fasciatus (Temminck \& Schlegel). J. Fish Dis. 13: 69-77

Manuscript first received: January 5, 1990

Revised version accepted: December 19, 1990 